\title{
Earthworm indicators as tools for soil monitoring, characterization and risk assessment. An example from the national Bioindicator programme (France)
}

\author{
Guénola Pérès ${ }^{a}, *$, Franck Vandenbulcke ${ }^{b, e}$, Muriel Guernion ${ }^{a}$, Mickaël Hedde ${ }^{c}$, Thierry Beguiristain ${ }^{\mathrm{d}}$, \\ Francis Douay ${ }^{\mathrm{e}}$, Sabine Houot ${ }^{\mathrm{f}}$, Denis Piron ${ }^{\mathrm{a}}$, Antoine Richard ${ }^{\mathrm{g}}$, Antonio Bispo ${ }^{\mathrm{h}}$, Cécile Grand ${ }^{\mathrm{h}}$, \\ Laurence Galsomies $^{\mathrm{h}}$, Daniel Cluzeau ${ }^{\mathrm{a}}$ \\ a University Rennes 1, UMR CNRS “Ecobio” 6553, Station Biologique, 35380 Paimpont, France

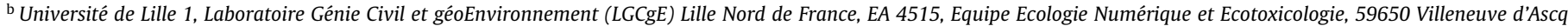 \\ Cedex, France \\ c PESSAC UR 251, INRA Versailles-Grignon, France \\ ${ }^{\mathrm{d}}$ LIMOS, UMR 7137 CNRS Nancy Université, Faculté des Sciences, Boulevard des Aiguillettes, BP 70239, 54506 Vandoeuvre-lès-Nancy Cedex, France \\ e Groupe ISA, Laboratoire Génie Civil et géoEnvironnement (LGCgE) Lille Nord de France, EA 4515, Equipe Sols et Environnement, 48 boulevard Vauban, 59046 Lille Cedex, France \\ f INRA Versailles-Grignon, UMR AgroParisTEch EGC “Environnement et Grandes Cultures”, BP 1, 78850 Thiverval-Grignon, France \\ ${ }^{g}$ INRA, US0010 Laboratoire d'Analyses, 273, rue de Cambrai, 62000 Arras, France \\ ${ }^{\mathrm{h}}$ ADEME (French Environment and Energy Management Agency), 20 avenue du Grésillé, BP 90 406, 49004 Angers Cedex 01, France
}

\section{A R T I C L E I N F O}

\section{Article history:}

Received 30 November 2010

Received in revised form

24 September 2011

Accepted 24 September 2011

\section{Keywords:}

Bioindicator

Monitoring

Risk assessment

Earthworm community

Metallothionein gene expression

\begin{abstract}
A B S T R A C T
Considering the limited number of bioindicators available to assess soil quality, a national research programme was set up in France to develop such indicators (2006-2012), the "Bioindicator" programme. This programme tested 47 biological parameters (i.e. microorganisms, fauna, flora) including earthworms, in several sites differing in terms of land use, contamination type - PAHs or metals - and pollution levels. The present study proposes some study objectives for bioindicator approaches, based on the earthworm results from the programme. Therefore, different earthworm descriptors were tested at the community level (e.g. abundance, biomass, species and functional structures, and ecological traits) as well as the organism level (i.e. measuring the metallothionein coding gene expression level in earthworms). The present results, obtained from the programme's spring 2009 sampling campaign, discriminated among the different descriptors and showed that earthworm and endogeic abundance as well as the individual weight of endogeics seem to be good indicators in non-contaminated (cultivated) sites, while the ecological structure, namely the proportion of anecic vs. endogeic species, and the proportion of non-vulnerable species should be used as indicators of contaminated soils. Furthermore, the first results obtained for Lumbricus terrestris and $L$. rubellus rubellus are encouraging as they show that metallothionein expression increases in metal-contaminated soils. The relevance of these descriptors, which have to be considered in study objectives, requires the analysis of 2010 results.
\end{abstract}

(c) 2011 Elsevier GmbH. All rights reserved.

\section{Introduction}

Soils deliver valuable ecosystem goods and services such as carbon storage and water filtering, which have to be maintained to ensure a sustainable environment and society (Lavelle and Spain 2001; Lavelle et al. 2006; Morvan et al. 2006). Assessment of soil quality, defined as the ability of soils to deliver ecosystem services in a sustainable way (Doran and Parkin 1994), has become a major research topic in the last two decades (Ruiz et al. 2011). However,

\footnotetext{
is This study was carried out at the laboratory of University of Rennes.

* Corresponding author. Tel.: +33 0299618 174; fax: +33 0299618187

E-mail address: guenola.peres@univ-rennes1.fr (G. Pérès).
}

it still requires validated tools able to inform state agencies, degradation and/or remediation of soil properties and functions, as well as monitoring networks (European Commission 2006). To date, soil characterization has generally been based on physical and chemical parameters (Morvan et al. 2008; Kibblewhite et al. 2008). However, soil organisms are known to respond to multiple impacts and to react quickly to natural and anthropic stresses, and could, therefore, be used as early warning indicators (Cortet et al. 1999; Sousa et al. 2005). Moreover, soil biodiversity is recognized both by the Convention on Biological Diversity (CBD) (UNCED 1992; www.cbd.int) and by the European Commission in the thematic strategy for soil protection (European Commission 2006) as essential for ecosystem functioning and the provisioning of soil services to humankind. Despite this recognition, biological tools are still rarely used in soil 
Table 1

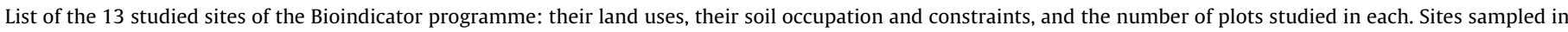
2009 are in bold.

\begin{tabular}{|c|c|c|c|c|}
\hline Site & Land uses & Soil occupation & Constraints & No. of plots \\
\hline 1 Thil & Cultivated & Arable & Soil tillage vs. no tillage & 4 \\
\hline 2 Gotheron & Cultivated & Orchard & Pesticides use & 6 \\
\hline 3 Qualiagro-Feucherolles & Cultivated & Arable & Inputs of organic matter residues & 5 \\
\hline 4 Yvetot & Cultivated & Arable, pastures & Age of pastures & 6 \\
\hline 5 Burre-ANDRA & Cultivated & Arable, pasture, forest & Different soil occupations & 3 \\
\hline 6 PS76 & Forest & Forest & Scots pine & 1 \\
\hline 7 EPC08 & Forest & Forest & Spruce & 1 \\
\hline 8 SP57 & Forest & Forest & Fir tree & 1 \\
\hline 9 EPC 63 & Forest & Forest & Spruce & 1 \\
\hline 10 Metaleurop & Contaminated & Arable, woodlands & Metal diffused contamination ( $\mathrm{Pb}, \mathrm{Cd}, \mathrm{Zn}$ ) & 7 \\
\hline 11 Auzon & Contaminated & Arable, pasture, woodlands & Local contamination (As) & 7 \\
\hline 12 Crassier métallurgique stéphanois & Contaminated & Wastelands & Metal contamination & 3 \\
\hline 13 GISFI & Contaminated & Wastelands & Contamination in $\mathrm{PAH}$ & 2 \\
\hline
\end{tabular}

monitoring networks and their integration is quite recent (Bispo et al. 2007; Cluzeau et al. 2009; Gardi et al. 2009; Rutgers et al. 2009; Dequiedt et al. 2011).

Considering that, at a national scale, there are very few validated biological tools to describe soil quality or to identify and prevent soil degradation, a national research programme, funded by the ADEME (French Environment and Energy Management Agency) has been set up in France to develop biological tools suitable for multiple stakeholders including industry (Bispo et al. 2009). This programme began with an independent evaluation of about 80 biological parameters (e.g. microorganisms, soil fauna, flora) based on biological diversity, activity, bioaccumulation of pollutants and physiological biomarkers (Bispo et al. 2009). The evaluation selected 47 relevant bioindicators of land use intensification, contamination intensity, and soil quality among the 80 parameters (Devillers et al. 2009). The selected parameters were, in a second step, assessed using spatial and temporal homogeneity (e.g. 13 sites were sampled during 2 sampling campaigns in 2009 and 2010). The main goals were (i) to calibrate the responses of these 47 selected parameters, namely to identify the range of their responses linked to the modification of land use, soil contamination, pedological characteristics, etc., (ii) to compare their relevance in terms of sensitivity - the quality of the response, their accessibility to specialists and non-specialists, and their applicability by experts or stakeholders, and (iii) to validate these parameters as bioindicators according to specific situations such as characterization, monitoring and assessment of soil quality or ecosystem risk.

Earthworms were part of the 47 selected indicators. Earthworms are currently considered good environmental indicator candidates since (i) they are well represented in the soil system in terms of density, (ii) they respond to a variety of environmental and ecological factors such as changes in soil chemistry, and forestry and agricultural practices, and (iii) they can be considered as an indicator of soil functioning due to their strong impact on soil (Bouché 1981; Lavelle and Spain 2001; Paoletti 1999; Tondoh et al. 2007; Pérès et al. 2008). Moreover, the first step of the Bioindicator programme demonstrated that at a community level, earthworm abundance can be used as an indicator of land use (e.g. arable land vs. meadow vs. forest) and other descriptors such as species richness and ecological structure (abundance of ecological groups) are indicators of fertilization and pesticide treatments (Cluzeau et al. 2009). Also, the relevance of using the metallothionein $(m t)$ gene expression in earthworms as a biomarker of cadmium exposure was previously demonstrated (Brulle and Vandenbulcke 2009). MTs are mainly known for their role in detoxification of metal trace elements such as $\mathrm{Cd}$ and in homeostasis of essential elements such as $\mathrm{Zn}$ (Bernard et al. 2010). MTs are also regarded as good biomarkers of metal exposure because they show dose and time-dependent increases in proteins and the number of transcripts coding MT when earthworms are exposed to TE contamination, especially Cd (Brulle et al. 2006; Demuynck et al. 2007).

Thus, our objectives in the second phase were to (i) record the range of earthworm responses, at the community and individual level, to environmental modifications such as organic amendment, metal contamination and Polycyclic Aromatic Hydrocarbons (PAH) contamination, and (ii) test different earthworm descriptors such as total abundance, ecological and specific structure, which are either commonly or ecological traits or $m t$ gene expression with respect to Cd levels, which are rarely used, in order to propose some study objectives for bioindicator approaches. This work presents the results obtained from the first sampling campaign of the national Bioindicator programme carried out in 2009 (5 sites, 16 plots).

\section{Materials and methods}

\section{Sampling site network}

Due to the large number of sites, biological and soil sampling in 2009 was limited to 5 sites (16 plots) from the 13 sites (47 plots) of the Bioindicator programme (Table 1 ). Sites were selected to include three categories (cultivated sites, forests and contaminated sites) and five land uses (forest, arable, pasture, woodland and wasteland). Biological and soil parameters were sampled in the spring when seasonal conditions (e.g. soil moisture and air temperature) favour soil organism activity. Details of the 2009 sampling sites are given below and plot characteristics are detailed in Table 2.

\section{Qualiagro-Feucherolles site}

The Qualiagro-Feucherolles experiment (a cultivated site, code FEU) is located at Feucherolles, in north-western France $(50 \mathrm{~km}$ west from Paris; $48^{\circ} 52^{\prime} \mathrm{N}, 1^{\circ} 57^{\prime} \mathrm{E}$ ). The climate is oceanic with a mean rainfall of $695 \mathrm{~mm}^{-1} \mathrm{yar}^{-1}$ and a mean annual temperature of $10.7^{\circ} \mathrm{C}$. The soil is cultivated following a wheat-maize rotation. Four types of organic amendments (e.g. exogeneous organic matter, EOMs) are compared to a control treatment (FEU-TE): (i) a biowaste compost (FEU-BIO) issued from the co-composting of green wastes and source-separated organic fractions of municipal solid wastes, (ii) a compost (FEU-DVB) issued from the co-composting of green wastes with sewage sludge, (iii) a farmyard manure (FEU-FUM), and (iv) a municipal solid waste compost (FEU-OMR) issued from the composting of residual solid wastes after removing dry and clean packaging. The five plots were distributed according to a randomized block design with four blocks. The organic amendments have been applied every two years in September on wheat stubble with a target dose of $\mathrm{C}, 4 \mathrm{Tha}^{-1}$. Since the beginning of the experiment (1998), 6 applications have been applied in 1998, 2000, 2002, 2004, 
Table 2

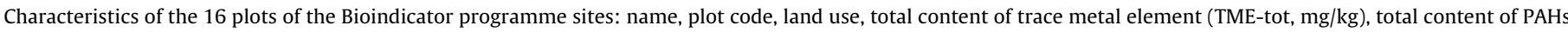

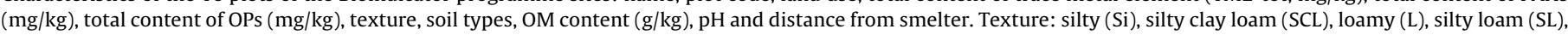

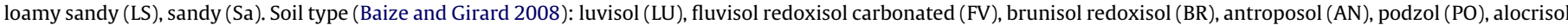
(AL). For quantitative value, the median value is used.

\begin{tabular}{|c|c|c|c|c|c|c|c|c|c|c|}
\hline Site name & Plot code & Land use & TME_tot & PAH_tot & OP_tot & Texture & Soil type & MO & $\mathrm{pH}$ & Distance \\
\hline \multirow[t]{5}{*}{ Qualiagro } & FEU-TE & Arable & 154.6 & 0.3 & 18.0 & $\mathrm{Si}$ & LU & 17.6 & 6.5 & \\
\hline & FEU-BIO & Arable & 165.9 & 0.3 & 25.0 & $\mathrm{Si}$ & LU & 25.1 & 7.5 & \\
\hline & FEU-DVB & Arable & 171.8 & 0.4 & 25.0 & $\mathrm{Si}$ & LU & 26.2 & 7.6 & \\
\hline & FEU-OMR & Arable & 172.6 & 0.3 & 18.0 & $\mathrm{Si}$ & LU & 21.4 & 7.9 & \\
\hline & FEU-FUM & Arable & 171.8 & 0.4 & 28.0 & $\mathrm{Si}$ & LU & 24.4 & 6.8 & \\
\hline \multirow[t]{7}{*}{ Metaleurop } & MET-HW & Woodland & 4556.7 & 2.0 & 7.8 & $\mathrm{SCL}$ & FV & 83.5 & 8.0 & $0.5 \mathrm{~km} \mathrm{E}$ \\
\hline & MET-IW & Woodland & 1596.6 & 0.5 & 5.4 & SCL & FV & 46.0 & 8.2 & $1 \mathrm{~km} \mathrm{E}$ \\
\hline & MET-IA & Arable & 1130.3 & 0.9 & 1.3 & SCL & FV & 45.1 & 8.2 & $1 \mathrm{~km} \mathrm{E}$ \\
\hline & MET-LW & Woodland & 755.1 & 1.7 & 1.2 & $\mathrm{~L}$ & BR & 55.0 & 6.5 & $3 \mathrm{~km} \mathrm{~N}$ \\
\hline & MET-LA & Arable & 457.5 & 1.0 & 1.8 & $\mathrm{~L}$ & BR & 29.3 & 7.9 & $3 \mathrm{~km} \mathrm{~N}$ \\
\hline & MET-RW & Woodland & 219.5 & 0.4 & 7.1 & SL & BR & 34.9 & 6.9 & $10 \mathrm{~km} \mathrm{NE}$ \\
\hline & MET-RA & Arable & 227.4 & 0.3 & 0.8 & SL & BR & 25.5 & 6.9 & $10 \mathrm{~km} \mathrm{NE}$ \\
\hline \multirow[t]{2}{*}{ GISFI } & GISFI-F & Wasteland & 745.8 & 60.5 & 1.8 & LS & AN & 209.0 & 8.2 & \\
\hline & GISFI-M & Wasteland & 925.7 & 572.2 & 1.8 & LS & AN & 363.0 & 8.2 & \\
\hline ЕРC08 & EPC-F08 & Forest & 198.8 & 0.8 & 1.0 & $\mathrm{~L}$ & PO & 151.0 & 4.0 & \\
\hline SP57 & SP-F57 & Forest & 40.5 & 0.1 & 0.4 & Sa & AL & 22.5 & 4.1 & \\
\hline
\end{tabular}

2006 and 2007. At the earthworm sampling date in March 2009, the field was sown with wheat.

\section{GISFI site}

The GISFI site is an industrial wasteland (a contaminated site, code GISFI), located at Homécourt ( $30 \mathrm{~km}$ west from Metz city, $\left.49^{\circ} 21367 \mathrm{~N}, 5^{\circ} 99608 \mathrm{E}\right)$, in north-eastern France. This experimental site of the French Scientific Interest Group - Industrial Wasteland (GISFI) (http://www.gisfi.fr) corresponds to a former industrial site with coking and metallurgical activities, closed in 1980. The climate is continental with a mean rainfall of $760 \mathrm{~mm}_{\text {year }}{ }^{-1}$ and a mean temperature of $10^{\circ} \mathrm{C}$. Soils were mainly contaminated with organic pollutants such as PAHs and metallic pollutants, and exhibited high spatial heterogeneity. The two studied plots (GISFI-F, GISFI-M) presented the same contamination origin but differed in terms of PAH levels and metal contamination (Table 2). The plots presented the same PAH profile dominated by PAH with 3 and 4 aromatic rings including fluoranthene, phenanthrene and pyrene while metal contamination was dominated by $\mathrm{Pb}, \mathrm{Zn}$, Mo and $\mathrm{Cd}$.

\section{Metaleurop site}

The Metaleurop site (a contaminated site, code MET) is located in northern France $\left(50^{\circ} 29^{\prime} \mathrm{N}, 2^{\circ} 59^{\prime} \mathrm{E}\right)$ and extends around the former lead smelter of Noyelles-Godault, closed in 2003. It corresponds to areas polluted by atmospheric emissions from the smelter with a gradient of metal pollution $(\mathrm{Cd}, \mathrm{Pb}, \mathrm{Zn})$ depending on the distance from the smelter (Table 2 ). The climate is oceanic with a continental tendency, with a mean rainfall of $744 \mathrm{~mm}$ year $^{-1}$ and a mean annual temperature of $10.8^{\circ} \mathrm{C}$.

Four areas were selected according to a metal pollution gradient in the vicinity $(\mathrm{H}, \mathrm{I}$ and $\mathrm{L}$ for high, intermediate and low, respectively) and at $10 \mathrm{~km}$ ( $\mathrm{R}$ for reference) from the former smelter, as well as two areas that had been used (woodland W and arable A) were studied. Due to French law, any arable plot must be located at least $0.5 \mathrm{~km}$ from the smelter. Characteristics of the 7 plots, i.e. METHW, MET-IW, MET-IA, MET-LW, MET-LA, MET-RW and MET-RA, are detailed in Table 2.

\section{Forest sites}

Two forest sites, which were part of the RENECOFOR network (http://www.onf.fr/renecofor), were studied. The ECP08 site, a common spruce forest (code F08), is located in the CroixScaille forest in northern France $\left(49^{\circ} 56^{\prime} \mathrm{N}, 4^{\circ} 48^{\prime} \mathrm{E}\right)$. The climate is semi-oceanic with a mean rainfall of $1090 \mathrm{~mm}_{\text {year }}{ }^{-1}$, a mean temperature of $10.8^{\circ} \mathrm{C}$ and the altitude is $470 \mathrm{~m}$ with an average slope of $6 \%$. The geological substrate is schist and the soil type is a podzol (Baize and Girard 2008) with loamy texture. The humus type is Moder. The SP57 site is a white fir forest (code F57) located in the Abreschviller forest in eastern France $\left(48^{\circ} 36^{\prime} \mathrm{N}, 7^{\circ} 8^{\prime} \mathrm{E}\right)$. The climate is continental with a mean rainfall of $785 \mathrm{~mm}$ year $^{-1}$, a mean temperature of $9^{\circ} \mathrm{C}$ and an altitude of $400 \mathrm{~m}$ with an average of slope $26 \%$. Geological substrate is sandstone and soil type is an alocrisol (Baize and Girard 2008) with a sandy loam texture and a Mull humus type.

\section{Sampling protocols, procedures and strategy}

The sampling protocol and procedure followed recommendations from the European programme ENVASSO (Bispo et al. 2007; Kibblewhite et al. 2008) and a previous framework from the national programme RMQS BioDiv (Cluzeau et al. 2009). In each site, the top soil and earthworms were sampled from March to April 2009. Sampling was carried out by the same 4 person team to ensure sample homogeneity and quality.

Two sampling strategies were developed. In non-randomized block sites (GISFI, Metaleurop, Forests) the parameters were sampled on a grid $(10 \mathrm{~m} \times 10 \mathrm{~m})$ subdivided into 4 sampling-zones $(5 \mathrm{~m} \times 5 \mathrm{~m})$ defining 4 sub-samples called REP as shown in Fig. 1 . In the randomized site (Qualiagro), the grid was split into the 4 randomized-blocks, defining 4 replicates (REP).

\section{Earthworms at the community level}

Earthworms were sampled using formaldehyde solution coupled with a hand sorting method (Bouché 1977; Cluzeau et al. 1999): three applications of 101 (formaldehyde concentrations: $0.25 \%, 0.25 \%, 0.4 \%$ ) were used on $1 \mathrm{~m}^{2}$ at $15 \mathrm{~min}$ intervals. Afterwards, remaining earthworms in the central $\mathrm{m}^{2}(25 \mathrm{~cm} \times 25 \mathrm{~cm}$, $25 \mathrm{~cm}$ depth) were collected by hand-sorting, to allow for data correction. Earthworms were preserved in a $4 \%$ formaldehyde solution. In the laboratory, the species were identified using Bouché's (1972) key, then lightly blotted with absorbent paper, and individually weighed.

The responses of earthworm communities were assessed via different descriptors: (i) their total abundance and biomass (ii) their ecological structure in relation to the proportion of three main morpho-ecological groups (epigeic, endogeic and anecic), (iii) their specific structure, species richness and diversity index (Shannon Index), (iv) morphological traits such as individual mean weight (IW epigeic adult, IW endogeic adult and IW anecic adult). In addition, earthworm vulnerability to soil pollutants was described 


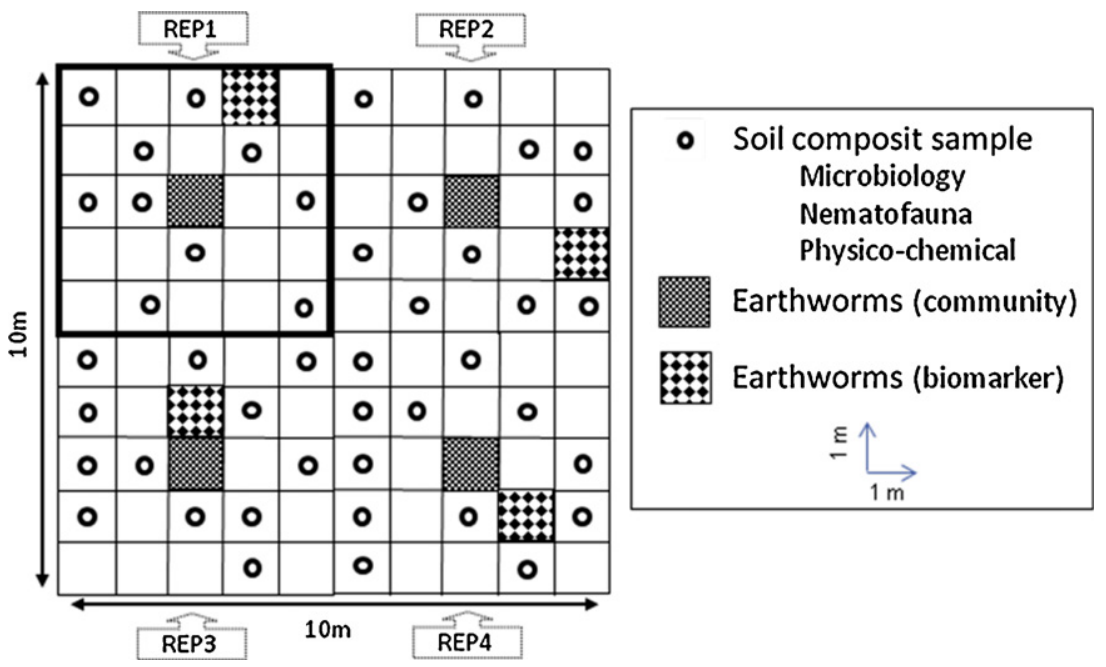

Fig. 1. Sampling design applied in each plot of the Bioindicator programme.

using five traits selected a priori in terms of exposure, sensitivity and population recovery (Table 3 ). Body pigmentation was proposed as a proxy for exposure. Surface earthworms, which are more deeply coloured, are the first to be exposed to pollutants that enter the soil. Sensitivity to exposure by contact was supposed to decrease with body wall thickness and exposure by ingestion was assessed by studying predominant earthworm food geophagous earthworms were considered more exposed than earthworms feeding on organic matter. Population recovery ability was assessed by species reproductive strategy and rate of occurrence in France. Obligatory or facultative parthenogenetic species should develop a new population more rapidly than strictly bi-parental species.
Population recovery also depends on how widespread the species is. We calculated this trait as the proportion of the $\sim 1400$ sites investigated by Bouché (1972) where the species was present. Data were obtained from Bouché (1972), Lowe and Butt (2007) and Diaz Cosin et al. (2011). We calculated the mean value for each dimension of vulnerability, and the index of species vulnerability was obtained by averaging the three dimensions. Species with lowest values were more vulnerable. Then, the non-vulnerable species proportion (nVP) in earthworm communities was calculated as the relative abundance of species weighted by its vulnerability index. Communities exhibiting high nVP values were then characterized by low proportions of vulnerable species.

Table 3

Trait attribute values per earthworm species. The species names are taken from Bouché (1972).

\begin{tabular}{|c|c|c|c|c|c|c|}
\hline & \multirow{2}{*}{$\begin{array}{l}\text { Exposure } \\
\text { Body } \\
\text { pigmentation }\end{array}$} & \multicolumn{2}{|l|}{ Sensitivity } & \multicolumn{3}{|l|}{ Population recovery } \\
\hline & & $\begin{array}{l}\text { Body wall thick } \\
\text { ness }\end{array}$ & Food & $\begin{array}{l}\text { Reproductive } \\
\text { strategy }\end{array}$ & Rarity & $\begin{array}{l}\text { Indice of species } \\
\text { vulnerability }\end{array}$ \\
\hline $\begin{array}{l}\text { Allolobophora chlorotica } \\
\text { chlorotica (Savigny, 1826) }\end{array}$ & 0.5 & 0.5 & 1 & 0 & 0.38 & 0.48 \\
\hline $\begin{array}{l}\text { Murchieona muldali (Omodeo, } \\
\text { 1956) }\end{array}$ & 0 & 0.5 & 1 & 0 & 0.04 & 0.26 \\
\hline $\begin{array}{l}\text { Aporrectodea rosea rosea } \\
\quad \text { (Savigny, 1826) }\end{array}$ & 0 & 0.5 & 1 & 1 & 0.35 & 0.47 \\
\hline $\begin{array}{l}\text { Satchellius mammalis mammalis } \\
\quad \text { (Savigny, 1826) }\end{array}$ & 1 & 1 & 0 & 0 & 0.10 & 0.52 \\
\hline $\begin{array}{l}\text { Dendrobaena octaedra (Savigny, } \\
\text { 1826) }\end{array}$ & 1 & 0.5 & 0 & 1 & 0.05 & 0.59 \\
\hline $\begin{array}{l}\text { Dendrodrilus rubidus rubidus } \\
\quad \text { (Savigny, 1826) }\end{array}$ & 1 & 0 & 0 & 1 & 0.05 & 0.51 \\
\hline $\begin{array}{l}\text { Eiseniella tetraedra tetraedra } \\
\quad \text { (Savigny, 1826) }\end{array}$ & 0.5 & 0.5 & 1 & 1 & 0.06 & 0.59 \\
\hline $\begin{array}{l}\text { Lumbricus castaneus (Savigny, } \\
\text { 1826) }\end{array}$ & 1 & 0.5 & 0 & 0 & 0.24 & 0.46 \\
\hline $\begin{array}{l}\text { Lumbricus castaneus disjonctus } \\
\text { (Savigny, 1826) }\end{array}$ & 1 & 0.5 & 0 & 0 & 0.06 & 0.43 \\
\hline $\begin{array}{l}\text { Lumbricus rubellus rubellus } \\
\text { (Hoffmeister, 1843) }\end{array}$ & 1 & 1 & 0 & 0 & 0.11 & 0.52 \\
\hline Lumbricus terrestris (Linné, 1758) & 1 & 1 & 0.5 & 0 & 0.21 & 0.58 \\
\hline $\begin{array}{l}\text { Aporrectodea caliginosa caliginosa } \\
\text { (Savigny, 1826) }\end{array}$ & 0 & 0 & 1 & 0 & 0.50 & 0.25 \\
\hline $\begin{array}{l}\text { Aporrectodea caliginosa } \\
\quad \text { meridionalis (Bouché, 1972) }\end{array}$ & 1 & 0.5 & 0.5 & 0 & 0.12 & 0.56 \\
\hline \multirow{2}{*}{$\begin{array}{l}\text { Octolasium lacteum lacteum } \\
\quad \text { (Orley, 1881) }\end{array}$} & 0 & 1 & 1 & 1 & 0.06 & 0.51 \\
\hline & $\begin{array}{l}\text { 1: Coloured } \\
0.5 \text { : slightly col } \\
0: \text { apigmented }\end{array}$ & $\begin{array}{l}1: \text { thick } \\
0.5: \text { interm. } \\
0: \text { thin }\end{array}$ & $\begin{array}{l}\text { 1: geophage } \\
0.5 \text { : intermediate } \\
0 \text { : saprophage }\end{array}$ & $\begin{array}{l}\text { 1: parthenogenetic } \\
0 \text { : biparental }\end{array}$ & $\begin{array}{l}->1: \text { widespread } \\
->0: \text { rare }\end{array}$ & \\
\hline
\end{tabular}

\footnotetext{
*\% of the $\sim 1400$ Bouché (1972) sites where the species was present.
} 
Expression of Cd-mt gene in individual earthworms (biomarker)

The metallothionein $(m t)$ gene expression is exclusively related to responses to cadmium levels in two Lumbricus species (Lumbricus terrestris and L. rubellus rubellus) originating only from contaminated sites. This Cd-mt gene expression was measured using PCR real-time performed on total RNAs extracted from complete earthworms (Brulle et al. 2011). Twelve individuals per species were sampled per plot, using the same method as described above. Then, earthworms were rinsed in water several times, put into their original soil and sent by express mail to the University of Lille. In the laboratory, earthworms were sacrificed for total RNA extraction. All expression analyses were conducted on total RNA extracted, using Tri-Reagent (Molecular Research Center, Inc, Cincinnati, USA) according to the manufacturer's instructions. RNA purity, integrity controls and reverse transcription were conducted as previously described (Brulle et al. 2006). Then, a retro transcription of RNA was done to obtain cDNA. Measurement of a reference gene ( $\beta$-actine) was also done by PCR real time. The availability of $C d$ - $m$ t and $\beta$-actin coding sequences in Genbank for $L$. terrestris and $L$. r. rubellus allowed us to design homologous primers, subsequently used in Real-Time quantitative PCR using the Light Cycler Probe Design Software version 1.0 (Roche Molecular Biochemicals, Mannheim, Germany). Homologous primers used for L. terrestris $m t$ were (forward 5'-CCA AGA GAG GGG TCA AC-3') and (reverse 5'-ACC ACA GCA TCC CTT C-3'), homologous primers used for $L$. terrestris $\beta$-actin are (forward 5'-AAC TCA CCA GCC ATG T-3') and (reverse $5^{\prime}$-CGT CGG GCA ATT CGT A-5'). Homologous primers used for $L$. r. rubellus $m t$ were (forward $5^{\prime}$-AAA TAA GAC ATG CCC AAG AG-3') and (reverse 5'-CAC CAC AGC ATC CTT TC-3'), homologous primers used for $L$. r. rubellus $\beta$-actin were (forward 5'-TCA ATC CCA AGG CCA AC-3') and (reverse $5^{\prime}$-ACG AAC GAT TTC ACG C$\left.3^{\prime}\right)$. Real-time PCR reactions were performed with a LightCycler apparatus (Roche Molecular Biochemicals, Germany) according to previously described procedures (Brulle et al. 2006, 2008). Levels of expression of the $m t$ target gene $(\mathrm{Tg})$ were compared to the expression of the constitutively expressed $\beta$-actin gene (25). The $C d-m t$ expression level was calculated according to the formula $R=(\mathrm{ETg}) \mathrm{CPTg} /$ (Eact)CPact.

\section{Explanatory variables}

In each $5 \mathrm{~m} \times 5 \mathrm{~m}$ sampling zone, 12 randomized soil samples were taken $(0-15 \mathrm{~cm}$ depth) and pooled to characterize soil physico-chemical parameters. Classic agro-pedological parameters were measured (e.g. texture, C, N, organic content, CEC, pH, Ca, $\mathrm{Mg}, \mathrm{Na}, \mathrm{K}, \mathrm{Fe}, \mathrm{Mn}, \mathrm{Al}$ ); total and bioavailable fraction (after $\mathrm{CaCl}_{2}$ $0.01 \mathrm{M}$ extraction) of metal elements were also measured ( $\mathrm{Co}, \mathrm{Cr}$, $\mathrm{Cu}, \mathrm{Ni}, \mathrm{Zn}, \mathrm{Pb}, \mathrm{Cd}, \mathrm{Tl}, \mathrm{Mo}, \mathrm{As}, \mathrm{Hg}$ ), as well as organic pollutants (16 PAHs, 26 herbicides and 12 organochlorine pesticides OCP). Trace elements were quantified by inductively coupled plasma - atomic emission spectrometry or mass spectrometry (ICP-AES or ICP-MS); organic pollutants were extracted by pressurized liquid extraction and quantified (i) by HPLC with diode array and fluorescence detector for $\mathrm{PAH}$, (ii) by gas chromatography with an electron-capture detector (GC-ECD) for OCP content, and (iii) by HPLC coupled with tandem mass spectrometry (HPLC-MSMS) for herbicides.

Moreover, the history (cultivation or contamination) of each site was recorded and integrated into the database to provide supporting information on the abiotic parameters.

\section{Data management and statistical analysis}

The response of earthworm communities to plot characteristics were tested by non-parametric Kruskal-Wallis tests $(0.05 \%$ significance level) followed by Bonferroni post hoc multiple comparisons to test differences between modalities. For the GISFI site, non-parametric Mann-Whitney tests (0.05\% significance level) were computed due to the limited number of plots (2). The relationships between earthworm parameters and abiotic parameters (e.g. physico-chemical data) were analyzed by multivariate analysis. First, PCA analyses were performed separately on earthworm parameters and physico-chemical data set. Co-inertia analysis was subsequently carried out to test for significant co-variation among the two data sets (Dray et al. 2003). The analyses were carried out with XLStat 2008 (Addinsoft) and open-source R statistical software version 2.11.0.

Concerning $\mathrm{mt}$ expression data, Student's t-tests were used. The normality of each distribution was verified by Kolmogorov-Smirnov's tests and variance homogeneity by Hartley's tests. A level of 0.05 was used in all procedures.

\section{Results}

\section{Earthworms at the community level}

Earthworm abundances are presented in Fig. 2. Forest sites (SP-F57 and EPC-F08) showed very low values of earthworm abundance, especially SP-F57 (2.75 individuals $\mathrm{m}^{-2}$ ); they also had a low species richness as only two earthworm species were sampled in each site with $L$.r. rubellus as a common species.

In the Qualiagro cultivated site, the addition of organic materials positively affected earthworm abundances compared with the control (FEU-TE: 58 individuals $\mathrm{m}^{-2}$ ), earthworm abundances were significantly higher in FEU-DVB (150 individuals $\mathrm{m}^{-2}$ ), FEUMOR (178 individuals $\mathrm{m}^{-2}$ ) and FE-FUM (318 individuals $\mathrm{m}^{-2}$ ). Regardless of treatment, earthworm communities were composed of endogeic species and anecic species, while epigeics were absent. In the control, endogeic individuals highly dominated the community in terms of abundance (77\%), while all organic amendments improved the ecological balance by encouraging anecic individuals, thus resulting in an earthworm community composed by $50 \%$ of both ecological groups. The species richness was very low on this site with only three earthworm species collected regardless of the plot. Aporrectodea caliginosa caliginosa dominated the endogeic species (average of 64 individuals per $\mathrm{m}^{2}$ ) while Aporrectodea rosea rosea was scarcely observed (average of 13 individuals per $\mathrm{m}^{2}$ ); $L$. terrestris was the only anecic species. The response of each species to organic amendments differed, especially for endogeic species: A. c. caliginosa was significantly stimulated by all organic amendments (excepted by FEU-BIO) while A. r. rosea was only affected by FEU-DVB inputs.

In the Metaleurop contaminated site, an interaction was observed between the effect of land use and contamination level. In the woodlands, earthworm abundances were significantly higher in control compared with contaminated plots, but within contaminated plots there was no relationship between earthworm abundance and metal contamination level. In arable plots, an intermediate level of metal contamination (MET-IA) strongly affected earthworm abundance compared with a low level of contamination (MET-LA) and the control (MET-RA); the control plot presented lower earthworm abundances than the minimally contaminated plots, which indicated that metal contamination was not the only factor affecting earthworms. The ecological structure of the community, i.e. the proportion of the different ecological groups, was impacted by the metal contamination as evidenced by the absence of endogeics in contaminated plots and the increase of epigeic individuals. Under woodlands, endogeic individuals were absent in all contaminated plots and the proportion of epigeics increased with the contamination gradient. In arable plots, endogeics were still present under low contamination levels (MET-LA) but were absent in intermediate contaminated plot (MET-IA). The species richness 


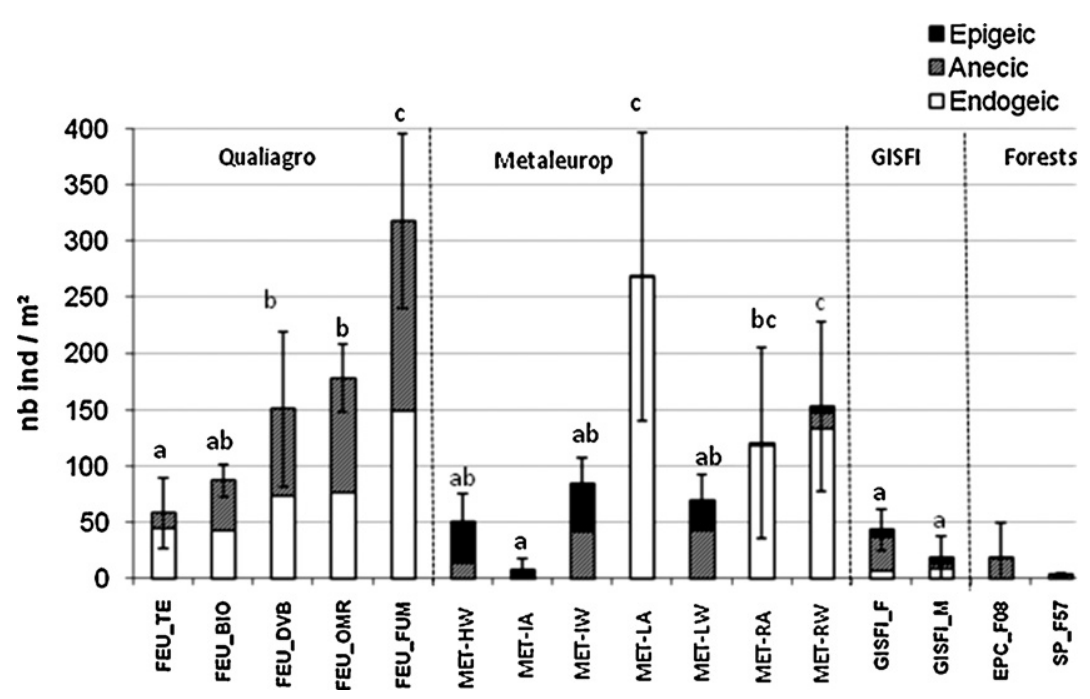

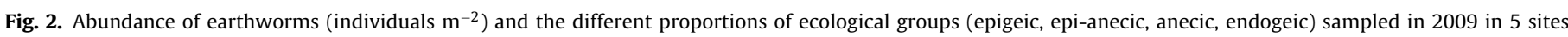

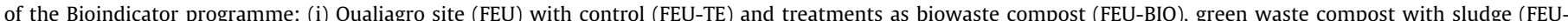

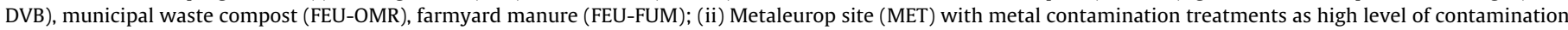

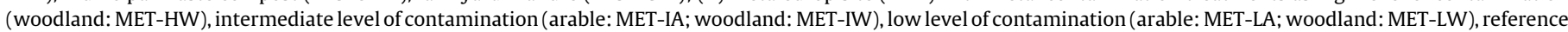

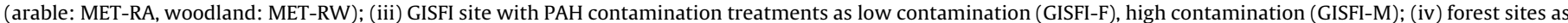
EPC08 (EPC-F08) and SP57 (SP-F57). Different letters indicate the significant effect of treatment within the studied sites $(P<0.05)$.

and species structure were also highly affected by metal contamination: (i) 7-8 species were collected in the control while only 3 species were collected in contaminated plots, (ii) A. c. caliginosa and A. $r$. rosea were absent in contaminated plots while they composed respectively $61 \%$ and $28 \%$ of the community in the arable control and $60 \%$ and $13 \%$ in control woodlands; some rare species (average abundance lower than 1 individual $\mathrm{m}^{-2}$ ) such as Octolasium lacteum lacteum and Dendrobaena mammalis were only observed in control plots.

In the GISFI contaminated wastelands, earthworm abundance was strongly affected by PAH contamination. The three ecological groups were present in both plots, but the ecological structure of the community was strongly modified by the level of PAH contamination: the proportion of anecics was significantly lower in the most contaminated plots (respectively $23 \%$ of the community in GISFI-M vs. 68\% in GISFI-F to), while the proportion of endogeics was significantly higher (48\% of the community in GISFI-M vs. $15 \%$ in GISFI-F). The species richness was not modified by PAH contamination, but specific structure changed in that some species such as $L$. terrestris and $A$. c. caliginosa were not in present at all in contaminated soil.

\section{Proportion of non-vulnerable species}

The proportion of non-vulnerable individuals did not change according to soil use or to plot factors. Mean proportion in each plot is depicted in Fig. 3. At the Qualiagro site, values were 22\% higher after the addition of OMR, FUM and BIO amendments compared to control soils. At the GISFI site and in forests, no difference was found, with mean index values of 0.51 and 0.52 , respectively. At the Metaleurop site, the lowest values were recorded in the reference plots (mean value of 0.32 ). Compared with the reference arable plot, the index was 1.4 and 1.6 times higher in low and intermediate contaminated arable plots, respectively. In contrast, woodland contaminated site results clearly showed the opposite trend of the reference plot $(0.31)$ with mean values between 0.50 and 0.53 , regardless of the level of contamination. Interestingly, no differences were found between reference plots of Metaleurop and QualiAgro control plot (MET-RW, MET-RA and FEU-TE).
Link between earthworm descriptors and soil physico-chemical characteristics

All earthworm data and physico-chemical data have been tested through PCA and co-inertia tests. Fig. 4 represented the most relevant parameters (parameters which contributed to axis construction). Significant co-variation (co-inertia analysis: $\mathrm{RV}=0.52$, $p$-value $=0.006$, Monte Carlo test) was observed among some earthworm descriptors and the physico-chemical data set (Fig. 4). The first axis of the co-inertia analysis (75\% variance explained) exhibited a gradient contrasting "non-contaminated" arable plots of Qualiagro and Metaleurop sites, to contaminated plots (Metaleurop and GISFI). Indeed, individual weight of epigeic adults (IW_epigeic_adult), epigeic abundance, anecic-endogeic ratio and the proportion of non-vulnerable species (nVP Proportion) were the earthworm descriptors linked to contaminated plots, identified by $\mathrm{CEC}$, extractible $\mathrm{Cu}$ and total contents of trace metal elements (TME). By contrast, earthworm descriptors which distinguished "non-contaminated" arable plots were the individual weight of endogeic adults (IW_endogeic_adult), endogeic abundance and total earthworm abundance associated with total content of OCPs. The second axis of the co-inertia analysis (16\% variance explained), separated plots according to the contamination's origin (metal contamination for Metaleurop vs. PAHs contamination in GISFI); the diversity index parameter was associated with organic matter, molybdenum and total contents of PAH which characterized GISFI plots.

\section{Expression of Cd-mt gene in individual earthworms (biomarker)}

For L. r. rubellus, the number of $C d$-mt coding transcripts was significantly higher in worms collected in the most metal polluted plot (MET-IA) compared with the number of transcripts in animals from the control (MET-RW), while there was no significant difference between the low contaminated plot (MET-LA) and control (MET-RW) (Fig. 5). Note that Cd-mt gene expression level was particularly low in L. r. rubellus originating from the GISFI-F and GISFI-M plots which were mainly polluted by PHAs. For L. terrestris, Cd-mt expression level was much higher $(P<0.05)$ in earthworms originating from the most metal polluted plots (MET-IW and 


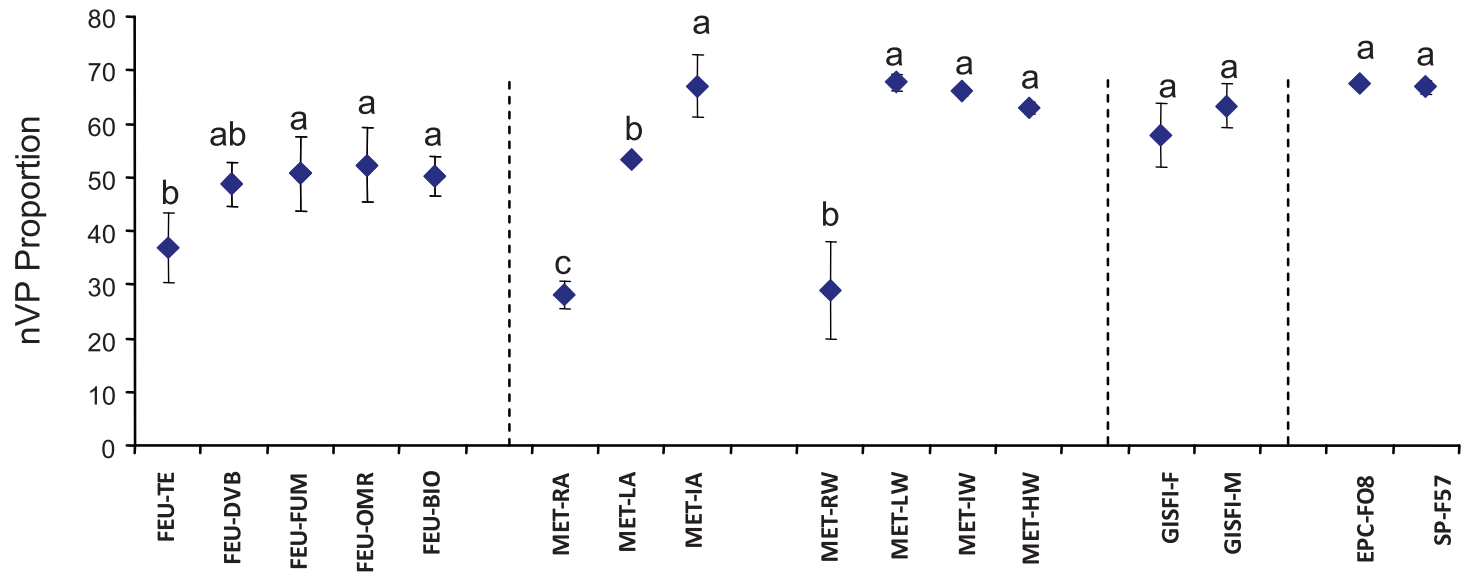

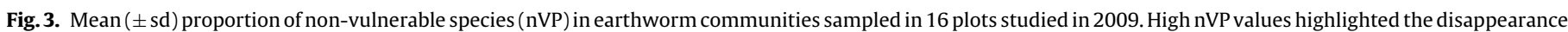
of the most vulnerable species. Different letters indicated differences in mean of plots for each site at the rejection level $\alpha=0.05$.
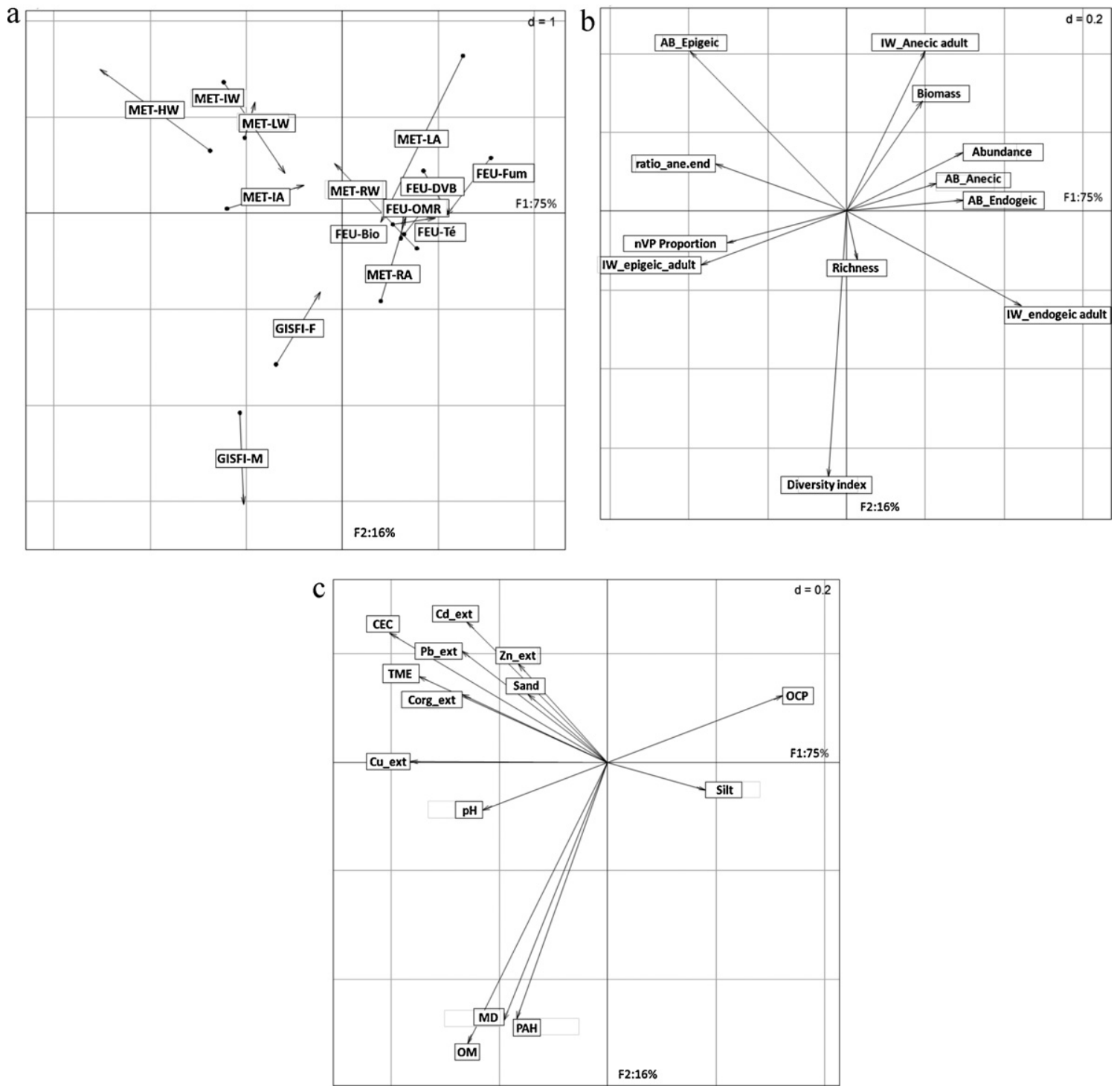

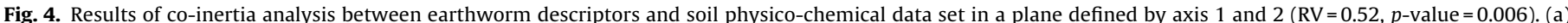

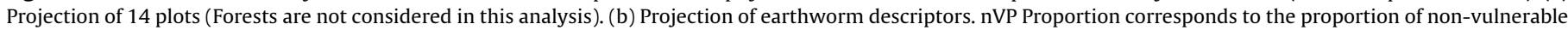
species. IW corresponds to individual weight. (c) Projection of soil physico-chemical parameters. 

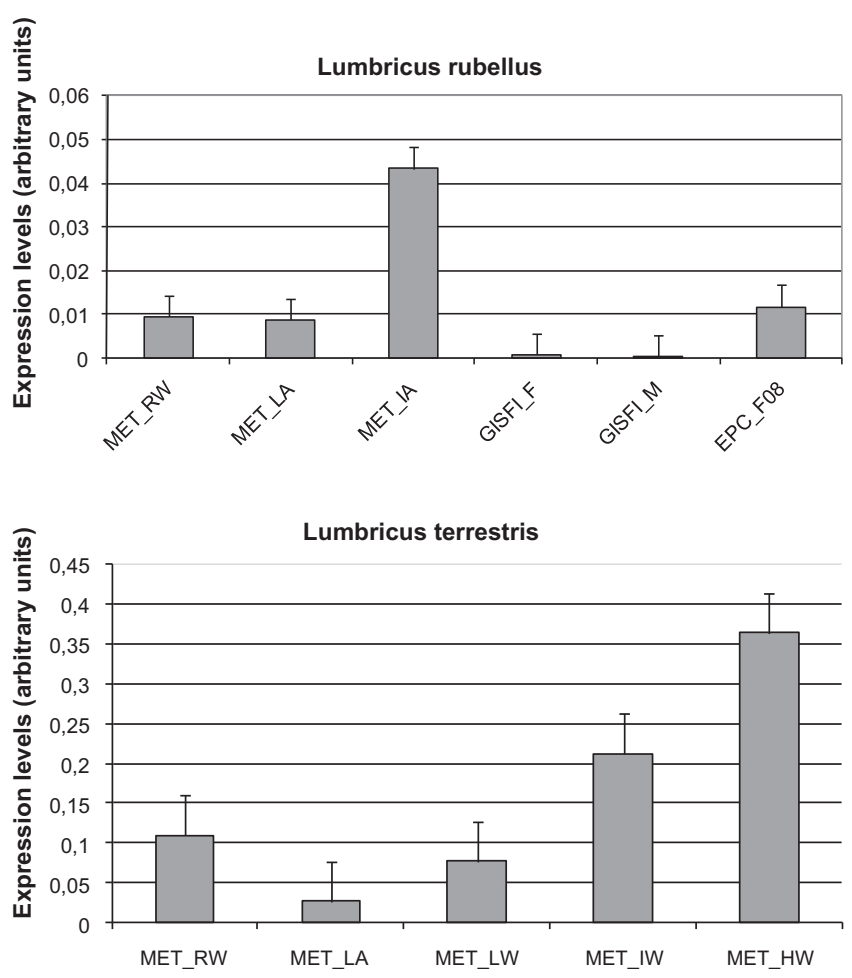

Fig. 5. Expression levels of $C d-m t$ for $L$. rubellus and $L$. terrestris measured in the Metaleurop site (reference woodland: MET-RW; arable with low level of contamination: MET-LA; woodland with low level of contamination: MET-LW; arable with intermediate level of contamination: MET-IA; woodland with intermediate level of contamination: MET-IW; woodland with high level of contamination: MET-HW), GISFI site (low contamination: GISFI-F; high contamination: GISFI-M) and forest sites (EPC-F08).

MET-HW) compared with control plots (MET-RW), while there were no differences between minimally-contaminated plots (METLW and MET-LA) and the control (MET-RW).

\section{Discussion}

\section{Earthworms at the community level}

In the cultivated site (Qualiagro), earthworm abundances corresponded to reference values obtained from the RMQS BioDiv programme (Cluzeau et al. 2009). No negative impacts of the solid waste composts (EOMs) were observed, in fact a favourable impact on earthworm density was recorded, supporting current observations in different agrosystems (Cotton and Curry 1980; Pérès et al. 1998) and a previous study on the same site (Capowiez et al. 2009). This result is usually explained by the addition of organic materials, which is the main limiting factor for earthworm communities in cultivated sites (Lee 1985). EOMs also impacted on the ecological structure as they allowed a better balance between both ecological groups - endogeic and anecic - by encouraging the development of anecics. The increase of anecics could be explained by the feeding behaviour of this group, which is saprophagous and therefore strongly affected by organic matter inputs, especially $L$. terrestris (Lee 1985). However EOMs did not impact species richness or specific composition. The low species richness ( 3 species) which was still low under amended plots and had not changed since 2004 (Capowiez et al. 2009), is often reported in arable fields and is explained by the drastic impact of tillage on the earthworm communities (Lee 1985; Chan 2001; Pérès et al., 2010). From our study, it appears that earthworm abundance, ecological composition or dietary characteristics, should be used as an indicator of the amount of organic inputs but not of the origin of the organic inputs. This last result contrasts with a previous study which demonstrated that the quality of the organic matter, in terms of $\mathrm{C} / \mathrm{N}$ content and/or presence of heavy metals could impact on earthworm communities differently (Edwards and Bohlen 1996). Nevertheless, changes in earthworm density and ecological balance with the increase of anecics, must be considered as important factor for soil functioning because anecics could affect (i) soil structure with an increase in macropore density and soil aggregation (Ligthart and Peek 1997; Pérès et al. 1998; Capowiez et al. 2009) and therefore, on water movement in soil (e.g. conductivity, retention) and on nutrient release and therefore, on soil fertility (Lee 1985). Thus, in a cultivated context, these descriptors should be used as indicators of soil quality.

In the metal contaminated site (Metaleurop), the impact of pollution on earthworms was moderated by land use, and as a result the earthworm density values reflected both pollution level and land use. In arable plots, earthworm abundance was more affected by agricultural practices than by the level of pollution, as earthworm density was higher in the low pollution level plot (MET-LA) compared with the reference arable plot (MET-RA). This could be related to the absence of tillage on MET-LA, reinforcing the strong impact of soil tillage on earthworm communities emphasized in the literature (Chan 2001). In woodlands, earthworm abundance was altered by metal pollution, which has been extensively reported on in the literature (Pizl and Josen 1995; Spurgeon and Hopkins 1999), but earthworm abundance could not distinguish between the levels of contamination assessed either by total metal concentration or by extractable fractions. This is not in accordance with results from Lukkari et al. (2004) who showed that total numbers of earthworms increased with decreasing metal pollution levels, but could be explained by the pollution levels of the studied sites, which is in our case 3-14 times higher than in the Lukkari et al. study. In contrast to the response of earthworm abundance, ecological structure seems to be a better indicator of pollution as endogeic were absent in all contaminated woodlands and also under arable plots for the intermediate level of metal contamination (MET-IA). This absence could be linked to (i) the soil location of endogeics which are directly in contact with metal pollutants, and (ii) the diet of endogeics which are geophagous and therefore ingest contaminated resources (Lee 1985). In the case of metal contamination, species richness also seemed to be a good indicator as the number of species strongly decreased in contaminated plots as previously found in other studies (Pizl and Josen 1995; Nahmani and Lavelle 2002). However the results for species richness did vary among pollution levels although this was demonstrated by Lukkari et al. (2004). These contrasting results emphasize that the relevance of earthworm descriptors, used as indicators of metal contamination levels, is strongly dependent on the range of assessed contamination levels, and on contaminant bioavailability. Moreover, the time since the last contaminant impact also determines whether the pollutant is more abundant in mineral soil (thus affecting endogeics) or in litter (affecting anecics or epigeics); therefore, future analysis of pollutant in litter should give us information of pollutant availability for saprophageous earthworms.

In industrial wastelands (GISFI) contaminated with PAHs and metals, earthworm abundance provided no information on contamination level $(P>0.05)$ even if abundances were higher under the lowest contaminated plot. In contrast, the ecological structure was once again strongly impacted by the PAH contamination as anecics decreased with PAH pollution balanced by an increase of endogeics. These results could be explained by the feeding behaviour of these ecological groups and by the fact that toxicity of PAHs is usually associated with the chronic risk that their exposure involves. However, in the case of a contaminated soil, Johnson et al. (2002) demonstrated that PAHs bioavailability was reduced 
with increased soil contact time; therefore, endogeics which are geophagous, are less exposed to $\mathrm{PAH}$ toxicity, while anecics are naturally more exposed to PAHs due to their niche. Once again, PAH contamination did not impact on species richness.

The concept of ecological vulnerability is remarkably reviewed in a paper of Lahr et al. (2010). Ecological vulnerability of a species describes the extent to which a species is potentially vulnerable to a stressor according to selected biological parameters. In our study, the proportion of vulnerable individuals in earthworm communities reflected soil disturbances in MetalEurop, GISFI and QualiAgro sites. Our results showed that the traits we considered a priori to be related to species vulnerability, permitted an assessment of soil disturbance. Currently, an increasing number of biological indicators is being developed using the operational concept of biological and ecological functional traits (Liess and von der Ohe 2005; De Lange et al. 2009; Rubach et al. 2010). The main strengths of such approaches lie (i) on the establishment of causal links, (ii) on its independency from taxonomy and (iii) on the possible generalization to similar habitats across eco-regions (Vandewalle et al. 2010). The present results suggest some independence of $\mathrm{nVP}$ ranges from soil occupancy that allows generalization over arable and deciduous forests. However, in MetalEurop plots nVP patterns differed according to soil land use. While the proportion of vulnerable species in arable plots tended to decrease regularly with metal contamination, a dichotomy appeared between reference soils and soils in polluted woodlands. This result could be explained by considering the bioavailability of trace metal contents rather than total contents (van Gestel 2008). For instance, $\mathrm{CaCl}_{2}$-extracted $\mathrm{Cd}$ was $80-550$ and $50-70 \mu \mathrm{g} \mathrm{kg}^{-1}$ in contaminated woodlands and arable plots, respectively. So, to achieve their full potential, trait-based approaches also required the accurate assessment of the stressor. In the case of soil pollution, organisms are exposed to different fractions of pollutants, either by contact (e.g. dissolved in soil solution) or by ingestion (sorbed on soil components) (Hedde et al. submitted for publication). At the GISFI site, no differences were recorded between the two plots. However, compared with the other sites, the nVP value indicated a low proportion of vulnerable species similar to that observed in the most contaminated plots of the MetalEurop site. Also, nVP can probably be considered for PAH-polluted soils. Finally, earthworm communities in uncontaminated coniferous forests exhibited the highest nVP values, highlighting the low proportion of vulnerable individuals. Coniferous forest soils often represent harsh conditions for earthworms (Curry 1998), notably low pH and soil compaction, which could have impaired vulnerable species. The nVP in Qualiagro trial soils separated control from plots spread with a biowaste compost, a municipal solid waste compost or a farmyard manure. No contaminants were found to explain this pattern. Two hypotheses can be proposed. First, although total pollutant contents were low, their localization in association with soil organic matter from the amendments can enhance exposure by ingestion. More probably however, the proposed index reflected counfounding factors rather than soil contamination. Hence, body colour was been chosen to reflect exposure to soil contaminants, but it was also connected to earthworm diet since the more coloured species were saprophagous (epigeic earthworms) or saprogeophagous (anecics).

The analysis, through descriptive approaches such as PCA and co-interia, of the relationships between earthworm descriptors and physico-chemicals parameters, reinforced all of these results obtained at the community level. It underlined the relevance of using ecological structure (i.e. the proportion of anecic vs. endogeic) and the proportion of non-vulnerable species as indicators of contaminated sites. Indeed, the proportion of vulnerable individuals in earthworm communities is a promising bioindicator for assessing soil pollutant impacts. Nevertheless, a dedicated trait-based tool is possibly required to evaluate the impact of organic amendments by taking into account soil organic matter quantity and quality in the definition of a priori causal mechanisms.

Our analyses also underlined the relevance of using earthworm abundance and the endogeic parameters (abundance or individual weight) in cultivated areas, associated with agricultural practices (e.g. use of pesticides such as OP).

\section{Expression of Cd-mt gene in individual earthworms (biomarker)}

Globally, results are consistent with the literature. Indeed, MTs are regarded as good biomarkers of metal exposure because they show dose and time-dependent increases in protein and the number of transcripts coding MTs when earthworms are exposed to TE contamination, especially Cd (Stürzenbaum et al. 2001; Morgan et al. 2004). Therefore, studies measuring the expression of MT in earthworms collected in the field are rare, as are studies measuring the expression of MT in uncontaminated worms exposed to natural soils (Brulle et al. 2011). The level of expression of Cd-MT was performed in field collected animals to see if this measure may be of interest from a "biomarker" point of view. In the present study, a low but significant induction of $C d-m t$ was detected in earthworms exposed to control soils. Such slight variations of $C d$ - $m$ t constitute a non-specific stress response (Bernard et al. 2010). Consequently, $C d-m t$ gene expression is specifically induced by metals, especially $\mathrm{Cd}$ but slight variations can be due to abiotic factors such as $\mathrm{pH}$ or organic matter content. Therefore, levels of $C d-m t$ expression were significantly higher in earthworms sampled in the most polluted plots. Indeed, the number of $C d-m t$ coding transcripts was significantly higher in L. r. rubellus and L. terrestris originating from the most metal polluted plots. Interestingly, compared to the reference in the Metaleurop site, the induction was not significantly higher in earthworms collected in the plot with the least contamination. This could be explained by the fact that the bioavailability of metals could be affected by soil parameters such as organic matter content or $\mathrm{pH}$ (Brusseau et al. 1997). Data-mining should enable identification of abiotic parameters that impact on the $C d$-mt gene expression level by affecting the bioavailability of metals in soil. Moreover, differences in species response to metal pollution cannot be excluded. The Bioindicator programme will hopefully elucidate this question since several species are being investigated, including new genus such as Allobophora and Nicodrilus. In conclusion, measurements of $C d$-mt expression levels in field-collected earthworms may inform the bioavailability of MTEs, especially Cd, in soils. Cd-mt gene expression does not seem to be very sensitive to the presence of other non-metallic pollutants. Therefore, we present preliminary results that must be confirmed. Indeed, studies carried out on animals collected from the field should consider adaptation and acclimation phenomena. Indeed, animals can face contamination in two ways: (i) adaptive responses and (ii) genetically programmed responses to a contaminant. This makes it difficult to distinguish between adaptation and acclimation making results difficult to interpret (see review Brulle et al. 2010).

\section{Conclusion}

This study, which has taken a prospective approach, offers some direction in using earthworm descriptors (more or less novel), at the community and individual (biomarker) levels, as indicators of soil quality or soil contamination. However, it has also underlined the limitations of some descriptors in several cases. Now, the relevance of these descriptors must be tested from different perspectives: (i) the robustness of the selected earthworm descriptors needs to be tested in a larger number of contexts, indeed, it is essential to evaluate their sensitivity in distinguishing between responses connected to natural parameters (abiotic 
factors, for example) from those connected to anthropic constraints (presence of a contaminant, organic matter inputs, agricultural practices); this shall be carried out using all the plots of the Bioindicator programme, which combine a large number of cultivated sites, contaminated sites and forests (at least 47 plots); (ii) the comparison of earthworm descriptors to the other 47 (microorganisms, fauna, flora) must be carried out to select a battery of indicators relevant for specific purposes (soil quality assessment, contamination risk assessment) according to specific objectives (these could be summarized as three key aspects: for whom, for what and when?); this analytical approach will be done through data-mining of the entire data set (biological and abiotic data) supported by statistical experts; moreover, this data-mining will allow data analyses according to bioindicators and objectives (e.g. revealing of dose responses, effect of the abiotic parameters on biologic parameters, data modelling, identification of complementarities/redundancies between tools, elaboration of reference values); (iii) the accessibility and transferability of the selected descriptors to stakeholders needs to be evaluated, as well as the cost/benefits of each descriptor; this will be achieved during the Bioindicator programme with collaboration of socio-economists and an "advice committee" composed of scientists and stakeholders (Ministry, Environmental Agency, Regional Board for Industry, Research and Environment, Farmers, Agricultural Agency, and others). Last but not least, the Bioindicator programme should permit the elaboration of a national reference database to facilitate the interpretation of bioindicators for soil protection and their use for monitoring or risk assessment.

\section{Acknowledgments}

The authors thank both Joël Clamart and François Mouchot for forest field supervisors for their valuable collaboration on field approaches, as well as Erwin Ulrich and Manuel Nicolas coordinators of RENECOFOR network. Our thanks also go to Vincent Mercier, Hoël Hotte and Valérie Briand for their technical support. The authors are grateful to Jennifer Harris-Hellal and Kevin R. Butt for their English revisions, and to the anonymous reviewers for their constructive criticism of the manuscript.

\section{References}

Baize, D., Girard, M.C., 2008. Référentiel pédologique. Association Française de l'Etude des Sols, Quae.

Bernard, F., Brulle, F., Donay, S., Lemière, S., Demuynck, Vandenbulcke, F., 2010. Metallic trace element body burdens and gene expression analysis of biomarker candidates in Eisenia fetida using an "exposure/depuration" experimental scheme with field soils. Ecotoxicol. Environ. Saf. 73, 1034-1045.

Bispo, A., Pérès, G., Cluzeau, D., Graefe, U., Römbke, J., Rutgers, M., Fuchs, M., Sousa, J.P., Schulte, R., Dombos, M., Simon, B., Gal, A., Cortet, J., Chaussod, R., Ritz, K., Creamer, R.E., Winding, A., English, M., Boixadera, J., Rubio, J., 2007. ENVASSO (Environmental assessment of soil for monitoring) WP 5-Decline in soil biodiversity. EU Contract No. 022713.

Bispo, A., Grand, C., Galsomies, L., 2009. Le programme ADEME "Bioindicateurs de qualité des sols": Vers le développement et la validation d'indicateurs biologiques pour la protection des sols. Et. Gest. Sols 16, 145-158.

Bouché, M.B., 1972. Lombriciens de France. Ecologie et Systématique. I.N.R.A. (Ann. Zool.-Ecol. Anim. $\mathrm{N}^{\circ}$ H.S. 72/2), Paris.

Bouché, M.B., 1977. Stratégies Lombriciennes. Bull. Ecol. Paris 25, 122-132.

Bouché, M.B., 1981. Lombriciens: biostimulation des sols et bio-indication. In: Compte rendu des Journées Science Eologique et Déloppement. AFIE, Grenoble, pp. 281-295, 19-20 September, 1979.

Brulle, F., Mitta, G., Cocquerelle, C., Vieau, D., Lemière, S., Leprêtre, A., Vandenbulcke, F., 2006. Cloning and real-time PCR testing of 14 potential biomarkers in Eisenia fetida following cadmium exposure. Environ. Sci. Technol. 40, 2844-2850.

Brulle, F., Cocquerelle, C., Wamalah, A.N., Morgan, A.J., Kille, P., Leprêtre, A., Vandenbulcke, F., 2008. cDNA cloning and expression analysis of Eisenia fetida (Annelida; Oligochaeta) phytochelatin synthase under cadmium exposure. Ecotox. Environ. Saf. 71, 47-55

Brulle, F., Vandenbulcke, F., 2009. Développement de Biomarqueurs d'exposition aux métaux bases sur des fonctions physiologiques de l'annélide oligochète Eisenia fetida. Et. Gest. Sols 16, 159-173.
Brulle, F., Morgan, A.J., Cocquerelle, C., Vandenbulcke, F., 2010. Transcriptomic underpinning of toxicant-mediated physiological function alterations in three terrestrial invertebrate taxa: a review. Environ. Pollut. 158, 2793-2808.

Brulle, F., Lemière, S., Waterlot, C., Douay, F., Vandenbulcke, F., 2011. Gene expression analysis of 4 biomarker candidates in eisenia fetida exposed to an environmental metallic trace elements gradient: A microcosm study. Science of the Total Environment 409 (24), 5470-5482.

Brusseau, M.L., Wang, X., Wang, W.Z., 1997. Simultaneous elution of heavy metals and organic compounds from soil by cyclodextrin. Environ. Sci. Technol. 31, 1087-1092.

Capowiez, Y., Rault, M., Mazzia, C., Lhoutellier, C., Houot, S., 2009. Étude des effets des apports de produits résiduaires organiques sur la macrofaune lombricienne en conditions de grandes cultures. Et. Gest. Sols 16, 175-185.

Chan, K.Y., 2001. An overview of some tillage impacts on earthworm population abundance and diversity: implications for functioning in soils. Soil Till. Res. 57 179-191.S.

Cluzeau, D., Cannavacciulo, M., Pérès, G., 1999. Indicateurs macrobiologiques des sols: les lombriciens - Méthode d'échantillonnage dans les agrosystèmes en zone tempérée. In: ITV (Ed.), Colloque Euroviti 1999-12ème Colloque Viticole et Enologique. Paris, pp. 25-35.

Cluzeau, D., Pérès, G., Guernion, M., Chaussod, R., Cortet, J., Fargette, M., MartinLaurent, F., Mateille, T., Pernin, C., Ponge, J.-F., et al., 2009. Intégration de la biodiversité des sols dans les réseaux de surveillance de la qualité des sols: exemple du programme-pilote à l'échelle régionale, le RMQS BioDiv. Et. Gest. Sols 16, 187-202.

Cortet, J., Gomot-De Vauflery, A., Poinsot-Balaguer, N., Gomot, L., Texier, C., Cluzeau, D., 1999. The use of invertebrate soil fauna in monitoring pollutant effects. Eur. J. Soil Sci. 35, 115-134.

Cotton, D.C.F., Curry, J.P., 1980. The effects of cattle and pig slurry fertilizers on earthworms (Oligochaeta, Lumbricidae) in grassland managed for silage production. Pedobiologia 20, 181-188.

Curry, J.P., 1998. Factors affecting earthworm abundance in soils. In: Edwards, C.A (Ed.), Earthworms Ecology. CRC Press LLC, Boca Raton, pp. 37-64.

De Lange, H.J., Lahr, J., Van der Pol, J.J.C., Wessels, Y., Faber, J.H., 2009. Ecological vulnerability in wildlife: an expert judgment and multicriteria analysis tool using ecological traits to assess relative impact of pollutants. Environ. Toxicol. Chem. $28,2233-2240$

Demuynck, S., Grumiaux, F., Mottier, V., Schikorski, D., Lemiere, S., Leprêtre, A., 2007. Cd/Zn exposure interactions on metallothionein response in Eisenia fetida (Annelida, Oligochaeta). Comp. Biochem. Phys. C 145, 658-668.

Dequiedt, S., Saby, N.P.A., Lelievre, M., Jolivet, C., Thioulouse, J., Toutain, B., Arrouays, D., Bispo, A., Lemanceau, P., Ranjard, L., 2011. Biogeographical patterns of soil molecular microbial biomass as influenced by soil characteristics and management. Global Ecol. Biogeogr. 20, 641-652.

Devillers, J., Pandard, P., Charissou, A.M., 2009. Sélection multicritère de bioindicateurs de la qualité des sols. Et. Gest. Sols 16, 233-242.

Diaz Cosin, D.J., Novo, M., Fernandez, R., 2011. Reproduction of earthworms: sexual selection and parthenogenesis. In: Karaca, A. (Ed.), Biology of Earthworms. Springer-Verlag, Berlin, Heidelberg.

Doran, J.W., Parkin, T.B., 1994. Defining and assessing soil quality. Defining Soil Quality for a Sustainable Environment. SSSA Special Publication 35, pp. 3-21.

Dray, S., Chessel, D., Thioulouse, J., 2003. Co-inertia analysis and the linking of ecological tables. Ecology 84, 3078-3089.

Edwards, C.A., Bohlen, P.J., 1996. Biology and Ecology of Earthworms. Chapman \& Hall, London, 426.

European Commission, 2006. Communication from the Commission to the Council, the European Parliament, the European Economic and Social Committee and the Committee of the regions: thematic strategy for soil protection. COM (2006), p. 231. http://ec.europa.eu/environment/soil/ (last accessed 04.04.07).

Gardi, C., Montanarella, L., Arrouays, D., Bispo, A., Lemanceau, P., Jolivet, C., Mulder, C., Ranjard, L., Römbke, J., Rutgers, M., Menta, C., 2009. Soil biodiversity monitoring in Europe: ongoing activities and challenges. Eur. J. Soil Sci. 60, 807-819.

Hedde, M., van Oort, F., Lamy, I. A trait-based approach to unravel availabilityexposure-impact chain of causality in metal polluted soils, submitted for publication.

Johnson, D.L., Jones, K.C., Langdon, C.J., Piearce, T.G., Semple, K.T., 2002. Temporal changes in earthworm availability and extractability of polycyclic aromatic hydrocarbons in soil. Soil Biol. Biochem. 34, 1363-1370.

Kibblewhite, M.G., Jones, R.J.A., Baritz, R., Huber, S., Arrouays, D., Micheli, E. Stephens, M., 2008. ENVASSO Final Report Part 1: Scientific and Technical Activities. ENVASSO Project (contract 022713) Coordinated by Cranfield University, UK for Scientific Support to Policy, European Commission 6th Framework Research Programme.

Lahr, J.B., Münier, H.J., De Lange, J.F., Faber, Sørensen, P.B., 2010. Wildlife vulnerability and risk maps for combined pollutants. Sci. Total Environ. 408, 3891-3898.

Lavelle, P., Decaëns, T., Aubert, M., Barot, S., Blouin, M., Bureau, F., Margerie, F., Mora P., Rossi, J.P., 2006. Soil invertebrates and ecosystem services. Eur. J. Soil Biol. 42, $3-15$.

Lavelle, P., Spain, A., 2001. Soil Ecology. Kluwer Scientific Publications, Amsterdam, The Netherlands.

Lee, K.E., 1985. Earthworms. Their Ecology and Relationships with Soil and Land Use. Academic Press, Sydney.

Liess, M., von der Ohe, P.C., 2005. Analyzing effects of pesticides on invertebrate communities in streams. Environ. Toxicol. Chem. 24, 954-965. 
Ligthart, T.N., Peek, G.J.W.C., 1997. Evolution of earthworm burrow systems after inoculation of lumbricid earthworms in a pasture in the Netherlands. Soil Biol. Biochem. 29, 453-462.

Lowe, C.N., Butt, K.R., 2007. Life cycle traits of the dimorphic earthworm species Allolobophora chlorotica (Savigny 1826) under controlled laboratory conditions. Biol. Fertil. Soil 43, 495-499.

Lukkari, T., Taavitsainen, M., Soimasuo, M., Oikari, A., Haimi, J., 2004. Biomarker responses of the earthworm Aporrectodea tuberculata to copper and zinc exposure: differences between populations with and without earlier metal exposure. Environ. Pollut. 129, 377-386.

Morvan, X., Mouvet, C., Baran, N., Gutierrez, A., 2006. Pesticides in the groundwater of a spring draining a sandy aquifer: temporal variability of concentrations and fluxes. J. Contam. Hydrol. 87, 176-190.

Morgan, A.J., Stürzenbaum, S.R., Winters, C., Grime, G.W., Nor Azwady Abd, A., Kille, P., 2004. Differential metallothionein expression in earthworm (Lumbricus rubellus) tissues. Ecotox. Environ. Saf. 57, 11-19.

Morvan, X., Saby, N., Arrouays, D., Le Bas, C., Jones, R., Verheijen, F., Bellamy, P., Stephens, M., Kibblewhite, M., 2008. Soil monitoring in Europe: a review of existing systems and requirements for harmonisation. Sci. Total Environ. 391, $1-12$.

Nahmani, J., Lavelle, P., 2002. Effects of heavy metal pollution on soil macrofauna in a grassland of Northern France. Eur. J. Soil Biol. 38, 297-300.

Paoletti, M.G., 1999. The role of earthworms for assessment of sustainability and as bioindicators. Agric. Ecocyst. Environ. 74, 137-155.

Pérès, G., Cluzeau, D., Curmi, P., Hallaire, V., 1998. Earthworm activity and soil structure changes due to organic enrichments in vineyard systems. Biol. Fertil. Soil 27, 417-424.

Pérès, G., Piron, D., Bellido, A., Goater, C., Cluzeau, D., 2008. Earthworms used as indicators of agricultural managements. Fresen. Environ. Bull. 17, 1181-1189.

Pérès, G., Bellido, A., Curmi, P., Marmonier, P., Cluzeau, D., 2010. Relationships between earthworm communities and burrow numbers under different land use systems. Pedobiologia 54, 37-44.
Pizl, V., Josen, G., 1995. The influence of traffic pollution on earthworms and their heavy metal content in urban ecosystem. Pedobiologia 39, 442-453.

Rubach, N.M., Ashauer, R., Buchwalter, D.B., De Lange, H.J., Hamer, M., Preuss, T.G., Töpke, K., Maund, S.J., 2010. Framework for traits-based assessment in ecotoxicology. Integr. Environ. Assess. Manag. 7, 172-186.

Ruiz, Nuria, Mathieu, J., Célini, L., Rollard, C., Hommay, G., Iorio, E., Lavelle, P., 2011. IBQS: a synthetic index of soil quality based on soil macro-invertebrate communities. Soil Biol. Biochem. 43, 2032-2045.

Rutgers, M., Schouten, A.J., Bloem, J., van Eekeren, N., de Goede, R.G.M., Jagersop Akkerhuis, G.A.J.M., van der Wal, A., Mulder, C., Brussaard, L., Breure, A.M., 2009. Biological measurements in a nationwide soil monitoring network. Eur. J. Soil Sci. 60, 820-832.

Sousa, J.P., Bolger, T., da Gama, M.M., Lukkari, T., Ponge, J.F., Simon, C., Traser, G., Vanbergen, A.J., Brennan, A., Dubs, F., Ivitis, E., Keating, A., Stofer, S., Watt, A.D., 2005. Changes in Collembola richness and diversity along a gradient of land-use intensity: a pan European study. Pedobiologia 50,147-156.

Spurgeon, D.J., Hopkins, S.P., 1999. Seasonal variation in the abundance, biomass and biodiversity of earthworms in smelter contaminated soils. J. Appl. Ecol. 36, $173-184$.

Stürzenbaum, S.R., Winters, C., Galay, M., Morgan, A.J., Kille, P., 2001. Metal ion trafficking in earthworms, Identification of a cadmium-specific metallothionein. J. Biol. Chem. 276, 34013-34018.

Tondoh, J.E., Monin, L.M., Tiho, S., Csuzdi, C., 2007. Can earthworms be used as bioindicators of land-use perturbations in semi-deciduous forest? Biol. Fert. Soils 43, 585-592.

UNCED, 1992. http://www.cbd.int/convention/text/.

Vandewalle, M., de Bello, F., Berg, M.P., Bolger, T., Doledec, S., Dubs, F., Feld, C.K., Harrington, R., Harrison, P.A., Lavorel, S., da Silva, P.M., Moretti, M., Niemela, J., Santos, P., Sattler, T., Sousa, J.P., Sykes, M.T., Vanbergen, A.J., Woodcock, B.A., 2010. Functional traits as indicators of biodiversity response to land use changes across ecosystems and organisms. Biodivers. Conserv. 19, 2921-2947.

van Gestel, C.A.M., 2008. Physico-chemical and biological parameters determine metal bioavailability in soils. Sci. Total Environ. 406, 385-395. 